\title{
Effect of Bisphenol A on the Levels of Vitellogenin and Metallothionein in Adult Male Carp, Cyprinus carpio carpio Linnaeus, 1758
}

\author{
Promy Virk, Amena Ali M Al-Sakran and Mai A Elobeid* \\ Department of Zoology, King Saud University, PO Box 22452, Riyadh-11495, Saudi Arabia
}

*For correspondence: Email: maielobeid@gmail.com; Tel: 966596404543

Received: 30 January 2014

Revised accepted: 2 June 2014

\begin{abstract}
Purpose: To investigate the potential role of bisphenol $A(B P A)$ in inducing endocrine disruption in fish. Methods: Adult male koi carps, Cyprinus carpio carpio $(n=60$, mean body weight $=125 \pm 12.288 \mathrm{~g}$ and mean length $=24 \pm 1.392 \mathrm{~cm}$ ) were exposed to three graded concentrations of BPA $(10,100$ and $1000 \mu \mathrm{g} / \mathrm{L}$ ) for a period of 21 days. A single dose of 17- $\beta$ estradiol (1 $\mathrm{ng} / \mathrm{l})$ was used as positive control. Results: The mean plasma concentration of vitellogenin (VTG) significantly increased in the carps exposed to $100 \mu \mathrm{g} B P A / L$ reaching a mean value of $14600.0 \pm 1400.0 \mathrm{ng} / \mathrm{ml}$ in comparison to $1140.00 \pm$ $34.64 \mathrm{ng} / \mathrm{ml}$ observed for the control group. However, BPA at all experimental concentrations had no significant effect on metallothionein levels in the liver, but the levels in the kidney were significantly decreased in all BPA-exposed groups in comparison to the level recorded for control (181.69 \pm 0.77 $\mathrm{pg} / \mathrm{g}$ wet tissue).

Conclusion: Exposure to BPA modulates plasma vitellogenin at median concentration and renal metallothionein levels at all concentrations in carp. Thus, these parameters are potential biomarkers in the biomonitoring of the aquatic environment for estrogenic chemicals.
\end{abstract}

Keywords: Carp, Bisphenol A, Vitellogenin, Metallothionein, Endocrine disruptors

Tropical Journal of Pharmaceutical Research is indexed by Science Citation Index (SciSearch), Scopus, International Pharmaceutical Abstract, Chemical Abstracts, Embase, Index Copernicus, EBSCO, African Index Medicus, JournalSeek, Journal Citation Reports/Science Edition, Directory of Open Access Journals (DOAJ), African Journal Online, Bioline International, Open-J-Gate and Pharmacy Abstracts

\section{INTRODUCTION}

Endocrine disrupting compounds (EDCs) is a term that encompasses a variety of anthropogenic chemicals including those that act as agonists and antagonists of the estrogen receptors (ERs), androgen receptor, thyroid hormone receptor, and others [1]. Estrogenic chemicals (ECs) such as some organochloride pesticides, polychlorinated biphenyls, plasticizers like phthalates and BPA, alkylphenolic compounds and natural and synthetic estrogens can interact with the estrogen receptor or alter estrogen metabolism, therefore mimicking the action of the natural steroid $17-\beta$-estradiol (E2)
[2]. The aquatic environment is an important area for the study of BPA due to the ubiquity of BPA in the aquatic environment [3]. Bisphenol $A$ is a nonsteroidal xenoestrogen that exhibits approximately $10^{-4}$ the activity of estradiol [4]. Most of the exposure studies on the estrogenic effect of BPA have focused on fish reproduction and a common biomarker has been the egg yolk protein precursor vitellogenin (VTG). VTG induction in response to BPA exposure has been widely reported in different fish species at environmentally relevant concentrations (11.0 $\mu \mathrm{g} / \mathrm{L})$ for 30 days [5] and at high BPA concentrations (100-1000 mg/L or more) for about 2-4 weeks $[6,7]$. 
Two isoforms of metallothioneins (MTs) are described in all vertebrates, including fish [8]. MT induction is considered as a response of an organism to physical or chemical stress and therefore it has been widely considered as a biomarker of exposure, especially to trace metals [9]. But previous studies have shown that an exposure to organic pollutants like EDCs can also modulate MT expression [10].

The present study was designed to assess the effect of three different concentrations of a xenoestrogen, BPA on the levels of plasma VTG and metallothionein (MT-2) in adult male koi carp (Cyprinus carpio carpio).

\section{EXPERIMENTAL}

\section{Fish}

One year old mature male koi carp (Cyprinus carpio carpio) $(\mathrm{n}=60$, mean body weight $=125 \pm$ $12.288 \mathrm{~g}$, and mean length $=24 \pm 1.392 \mathrm{~cm}$ ) were obtained from a local fish farm in Al-Qassim near Riyadh City in October 2012. In the laboratory the fish were divided into eight groups of 10 fish each. Prior to the experimental period the fish were acclimatized to the laboratory conditions for 15 days. During this period, each glass aquarium was filled with $100 \mathrm{~L}$ of aerated and de-chlorinated tap water and a natural $12 \mathrm{~h}$ light: $12 \mathrm{~h}$ dark schedule was maintained. Temperatures were maintained between $24-26$ ${ }^{\circ} \mathrm{C}$. During the acclimatization and exposure period fish were fed a commercial diet of dry pellet feed at $1 \%$ body weight per day. All animal procedures were performed in accordance with the standards set forth in the Guidelines for the Care and Use of Experimental Animals by the Committee for the Purpose of Control and Supervision of Experiments on Animals (CPCSEA) and the National Institutes of Health (NIH) [11].The study protocol was approved by the Animal Ethics Committee of the Zoology Department, College of Science, King Saud University (approval no. 799432).

\section{BPA exposure}

Following acclimatization the fish were separately exposed to three different waterborne concentrations of BPA $(10,100,1000 \mu \mathrm{g} / \mathrm{L})$ for 21 days. Analytical grade BPA (98 \%, Lobachemie, India) was used as the test xenoestrogen and $17-\beta$-Estradiol (E2) (97\%, Lobachemie, India) was used as a positive control. Stock solutions of both chemicals were prepared in acetone (99.5 $\%$, chartab S.L, Spain). The stock solutions were used to prepare the three dosing test solutions with nominal concentrations of BPA (10, 100 and $1000 \mu \mathrm{g} / \mathrm{L}$ ) and one test solution with nominal concentration of E2 $(1 \mathrm{ng} / \mathrm{L})$. The amount of acetone in aqueous solutions of chemicals was less than $100 \mu \mathrm{l} / \mathrm{L}$. Two glass aquaria were negative controls, one receiving only dechlorinated tap water while the other was the vehicle control.

During the exposure period, the water, BPA, E2 and acetone in each glass aquaria were changed after 7 days and the physicochemical parameters of water were analyzed at regular intervals to ensure they were in the conducive range. After 21 days of exposure seven fish from each group were taken out and anaesthetized. Body weight and the total length of each fish were recorded to the nearest gram and centimeter respectively to assess the condition factor. Blood $(1 \mathrm{ml})$ was collected in heparinized tubes from the anaesthetized fish using the heart puncture technique. After this the fish were sacrificed, the liver and testis were dissected out and weighed separately to assess their MT-2 levels. All tissues were stored at $-80{ }^{\circ} \mathrm{C}$ for three weeks till further analysis.

\section{Determination of physicochemical parameters of water}

Water samples from each tank were collected at weekly interval to analyse the basic physicochemical parameters namely, $\mathrm{pH}$, dissolved oxygen (DO) and total alkalinity. The $\mathrm{pH}$ of water samples was recorded using a digital $\mathrm{pH}$ meter (PB-11 Sartorius). Dissolved oxygen was measured using a DO meter with Galvanic Probe (Adwa AD610). Total Alkalinity (phenolphthalein and methyl orange) was determined following the standard volumetric method [12].

\section{Vitellogenin determination}

Measurement of VTG in the blood plasma was performed using a pre-coated ELISA kit (Wuhan EIA Lab Science Co. Ltd, China). The 96-well polystyrene microtiter plates were supplied precoated with carp VTG monoclonal antibody.

The blood collected in heparinized tubes was centrifuged at $1000 \times \mathrm{g}$ for $15 \mathrm{~min}$ at $2-8{ }^{\circ} \mathrm{C}$ within $30 \mathrm{~min}$ of collection. The plasma was stored in vials at $-80{ }^{\circ} \mathrm{C}$ until subsequent analysis. The assay was performed in accordance to the protocol provided with the enzyme assay kit. The concentrations of VTG in the samples were read from the standard curve and expressed as $\mathrm{ng} / \mathrm{ml}$. Since the samples were diluted 3-fold, the VTG concentrations read were multiplied by a dilution factor of 3 . 


\section{Metallothionein determination}

Measurement of metallothionein (MT-2) in the liver and kidney was carried out using a precoated ELISA kit (Mybiosource, USA). The 96well polystyrene microtiter plates were supplied precoated with antibody specific to fish MT-2. Tissue samples of liver and kidney were taken out from the freezer and left at room temperature for $1 \mathrm{~h}$. Each sample $(0.5 \mathrm{~g})$ was weighed and homogenized using $10 \mathrm{ml}$ of $1 \mathrm{X}$ PBS buffer (phosphate buffer concentration of $0.01 \mathrm{M}$ and $\mathrm{pH}$ 7.4). After homogenizing for 20 - $30 \mathrm{~min}$ the turbid liquid was collected in Eppendorf tubes and stored overnight at $-20{ }^{\circ} \mathrm{C}$. After two freezethaw cycles were performed to rupture the cell membranes, the homogenates were centrifuged for $5 \mathrm{~min}$ at $5000 \mathrm{x} \mathrm{g}$. The supernatant was stored at $-20{ }^{\circ} \mathrm{C}$ for subsequent assay. The assay was performed in accordance to the protocol provided with the ELISA kit. The concentrations of MT-2 in the samples were read from the standard curve and expressed as $\mathrm{pg} / \mathrm{g}$ of wet tissue.

\section{Statistical analysis}

All presented data are expressed as mean values \pm standard deviation (SD). One-way analysis of variance (ANOVA) was performed followed by an unpaired Student's t-test to analyze group differences. Numerical data was correlated with SPSS 16.0 statistical software (Chicago, IL, USA). The significance level was set at $p \leq 0.05$.

\section{RESULTS}

\section{Physicochemical characteristics}

Exposure to the BPA and the E2 levels used in the present study did not cause any mortality. The mean values of the physico-chemical parameters (DO, Total alkalinity, Temperature and $\mathrm{pH}$ ) of water in the experimental tanks were within the conducive range during the experimental period (Table 1).

Table 1: Physicochemical characteristics of water in experimental tanks over a 3-week exposure period

\begin{tabular}{lccc}
\hline Parameter & Week 1 & Week 2 & Week 3 \\
\hline DO $(\mathrm{mg} / \mathrm{L})$ & $5.03 \pm 0.15$ & $5.03 \pm 0.05$ & $5.00 \pm 0.10$ \\
Temp $\left({ }^{\circ} \mathrm{C}\right)$ & $29.66 \pm 0.57$ & $30.33 \pm 0.57$ & $29.66 \pm 0.57$ \\
TA $(\mathrm{mg} / \mathrm{L})$ & $34.66 \pm 1.15$ & $35.33 \pm 1.15$ & $34.00 \pm 0.0$ \\
$\mathrm{pH}$ & $7.1 \pm 0.17$ & $7.03 \pm 0.05$ & $7.1 \pm 0.0$ \\
\hline Values are mean $\pm S D(n=3) ; \quad D O=$ & dissolved \\
oxygen; TA $=$ total alkalinity & &
\end{tabular}

\section{Plasma vitellogenin levels}

At the end of the exposure period, plasma VTG concentrations of control carps were $1140.00 \pm$ $34.64 \mathrm{ng} / \mathrm{ml}$. There was no significant difference observed in the VTG concentrations of the carps from control $(1140.00 \pm 34.64 \mathrm{ng} / \mathrm{ml})$ and solvent control $(1120.00 \pm 40.00 \mathrm{ng} / \mathrm{ml})$ groups. The carps from the B2 group exposed to $100 \mu \mathrm{g}$ $\mathrm{BPA} / \mathrm{L}$ showed highly significant $(p \leq 0.001)$ induction of plasma VTG (Fig.1) reaching mean

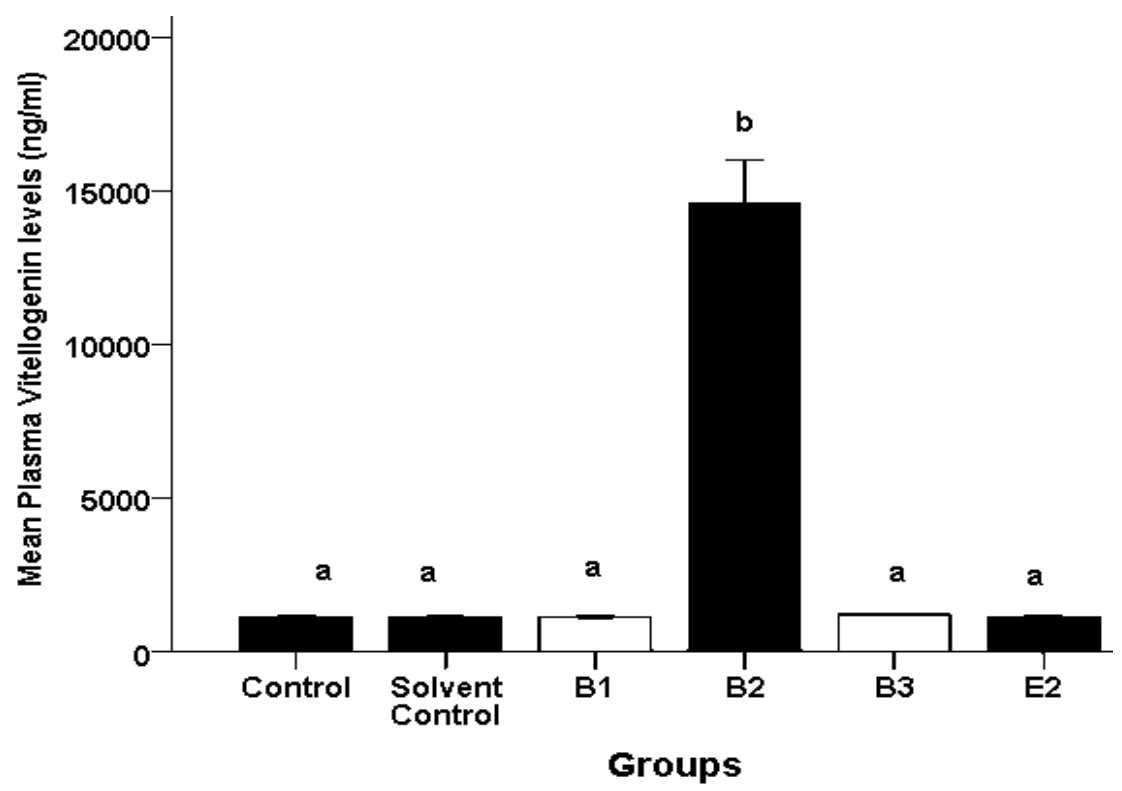

Figure 1: Plasma vitellogenin levels $(\mathrm{ng} / \mathrm{mL})$ of the carps exposed to the three concentrations of BPA, $10 \mu \mathrm{g} / \mathrm{L}$

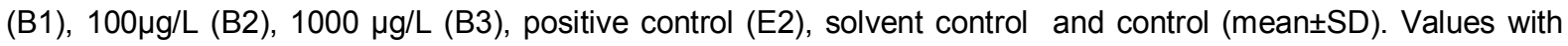
different letters are significantly different $(p<0.05)$ 


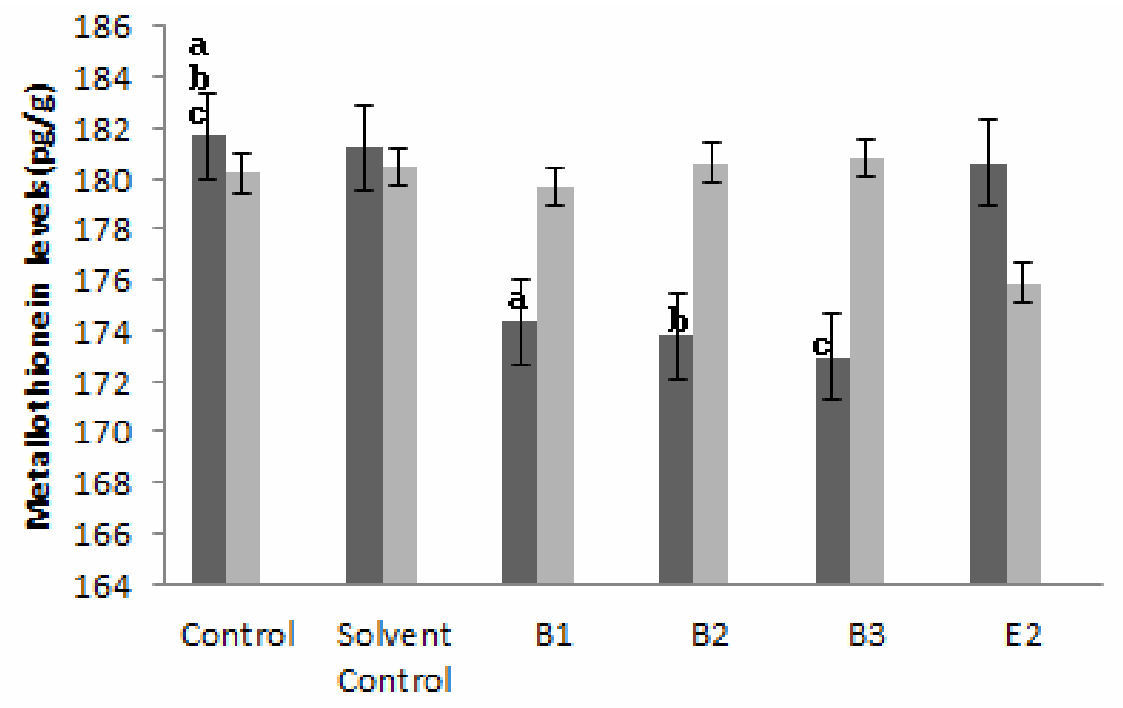

Groups

Figure 2: Metallothionein (MT-2) levels (pg/g) in the liver and kidney of the carps exposed to the three concentrations of BPA, $10 \mu \mathrm{g} / \mathrm{L}$ (B1), $100 \mu \mathrm{g} / \mathrm{L}$ (B2), $1000 \mu \mathrm{g} / \mathrm{L}$ (B3), positive control (E2), solvent control and control(Mean \pm SD). Values with different letters are significantly different $(p<0.05)$. Kidney $(\omega)$ Liver $(\square)$

values of $14600.00 \pm 1400.00 \mathrm{ng} / \mathrm{ml}$. The plasma VTG concentrations of carps from other experimental groups, B1 (10 $\mu \mathrm{g}$ BPA/L), B3 (1000 $\mu \mathrm{g} \mathrm{BPA/L)}$ and E2 (1 ng E2/L) were not significantly different from the control group.

\section{Metallothionein}

The mean value of the metallothionein (MT-2) levels in the liver of carps of the control group was $180.18 \pm 1.69$, which was comparable to the value for solvent control group (180.47 \pm 1.19 $\mathrm{pg} / \mathrm{g}$ wet tissue). There was no significant difference observed in the MT-2 levels in the liver of carps exposed to the estrogenic chemicals $(10,100,1000 \mu \mathrm{g} B P A / L$ and $1 \mathrm{ng} \mathrm{E2/L)} \mathrm{in}$ comparison to the control (Fig 2).

MT-2 levels in the kidney of the carps from the control and the solvent control were $181.69 \pm$ $0.77 \mathrm{pg} / \mathrm{g}$ wet tissue and $181.2000 \pm 0.52367$ $\mathrm{pg} / \mathrm{g}$ wet tissue respectively.

Carps from all three groups exposed to BPA (10, $100,1000 \mu \mathrm{g} / \mathrm{L})$ showed a significant decrease in the levels of MT-2 in comparison to the control group, being highly significant $(p \leq 0.001)$ at $\mathrm{B} 2$ and B3 with values of $173.78 \pm 1.29 \mathrm{pg} / \mathrm{g}$ wet tissue and $172.92 \pm 1.00 \mathrm{pg} / \mathrm{g}$ wet tissue respectively (Fig 2). The carps from the group exposed to E2 (1 ng /L) did not show a significant difference in the kidney MT-2 levels from the control group.

\section{DISCUSSION}

VTG, a yolk precursor protein synthesized in the liver is normally associated with female fish and is taken up by the ovaries, in males it is either absent or at very low concentrations [13]. However, male fish also possess the hepatocyte estrogen receptor (ER) and can synthesize VTG when exposed to E2 or other estrogen mimetics. Its metabolism in males is slow. Thus its presence in oviparous fish, particularly in males, makes it an ideal biomarker for studies on the effect of estrogenic EDCs on fish.

The results obtained in this study demonstrate the mild estrogenicity of BPA on fish in terms of VTG induction at the median concentration (100 $\mu \mathrm{g} / \mathrm{L})$. Induction of VTG due to BPA exposure has been reported in several fishes, although LOECs used in most of the exposure studies are generally above environmental levels. A significant increase in VTG has been reported in adult common carp [7] and Japanese medaka [14] at $1000 \mu \mathrm{g} / \mathrm{L}$ BPA after 14 and 21 days exposure, respectively. Further, Lindholst et al [6] observed VTG induction in rainbow trout exposed to $500 \mu \mathrm{g} / \mathrm{L}$ BPA for 12 days. While an exposure to 460 and $160 \mu \mathrm{g} / \mathrm{L}$ BPA showed detectable levels of VTG in fathead minnows after 43 and 71 days respectively [15].

There have been studies where an exposure to BPA at environmentally relevant concentrations of $10 \mu \mathrm{g} / \mathrm{L}$ and $11 \mu \mathrm{g} / \mathrm{L}$ significantly induced VTG 
in juvenile seabass (Dicentrarchu s labrax) and in the male gold fish (Carassius auratus) respectively following a 30 day exposure $[5,16]$. Our findings also showed a significant induction in the VTG levels of male common carp exposed to BPA at a concentration of $100 \mu \mathrm{g} / \mathrm{L}$ for 21 days. However, the lower $(10 \mu \mathrm{g} / \mathrm{L})$ and the higher $(1000 \mu \mathrm{g} / \mathrm{L})$ concentrations of BPA used in our study did not show a significant increase in the plasma VTG levels of the carp and were comparable to the control group.

Previous studies $(5-7,14,15)$ reported that much variation exists among fish species in the ability of BPA to elevate serum or plasma VTG. Sensitivity differences in VTG induction by BPA can be attributed to several factors. Variation in VTG induction across the taxa is likely due to species-specific ER binding affinities, metabolic rates, while within the same species the variability could be due to the difference in study design based on sex, age and maturity of the fish along with the exposure time [17]. The pattern of VTG induction in the present study has been different as the effect of BPA at the median concentration $(100 \mu \mathrm{g} / \mathrm{L})$ was more detectable. This is explained by the non-linear relationship between the three doses of BPA on plasma VTG induction which demonstrates an inverted $\mathrm{U}$ shaped dose-effect curve" (IUSDEC).

vom Saal and Hughes [18] have extensively reviewed the literature on low-dose effect of BPA and have reported the importance of an inverted$U$ dose-response phenomenon in studies of chemicals such as BPA which is relevant for assessing the possibility of unique effects that only occur within a specific low-dose range. This does support the findings of the present study which did not reflect a linear dose- dependent response of BPA on VTG induction in carp.

Metallothioneins are highly conserved proteins responsible for metal sequestration and detoxification with their induction being affected by metals and other chemicals stressors in the environment [19]. Although the induction of VTG by estrogens is well established, the effect of estrogens on MT in fish is not fully understood. A study by Werner et al [20] showed that exposure to waterborne ethynylestradiol (EE2) in lake trout at high and medium EE2 concentrations (40 and $400 \mathrm{ng} / \mathrm{L})$, reflected a decrease in MT concentration in the liver corroborating the findings described for Rhamda quelen exposed to a high dose of E2 $(10 \mathrm{mg} / \mathrm{kg})$ [21]. While the lower concentration of EE2 (4 ng/L) and E2 $(0.1,1.0 \mathrm{mg} / \mathrm{kg})$ used in these studies failed to modulate the hepatic MT levels and were comparable to the control. Thus the estrogenic chemicals are able to modulate the MT levels at a concentration above the threshold level.

The findings of our study on the MT-2 levels in the liver of carps exposed to all three concentrations of BPA demonstrate the mild estrogenicity of BPA (corresponding to a level below the threshold level) which failed to elicit a change in the MT levels in the liver. However, our results on MT-2 levels in the kidney showed a decrease for all the groups exposed to BPA. This is in concord with the study by Rhee et al [10] where an exposure of mangrove killifish, to different EDCs had a suppressive effect on the MT expression in liver, brain gonads and intestines, being most significant with BPA at a single dose of $600 \mu \mathrm{g} / \mathrm{L}$, which was within the range of doses of BPA used in the current study. It has been reported that there are several factors that influence MT expression, such as age, sex and tissue type, both in the control and exposed fishes [10]. Thus, studies on the effect of MT expression in fish show that MT gene expression is differentially regulated by metals and EDCs and there are varied results on the effect of EDCs on the MT induction in fish. Most previous studies [20,21] assessed the effect of natural estrogens (E2, EE2) on MT modulation in liver and kidney of fish. These studies have mainly focused on the role of MT in metal sequestration during vitellogenesis, a process controlled by endogenous estrogens in fish. Xenoestrogens, such as, BPA can also modulate the MT-levels in fish exhibiting a general downregulation in various tissues, a trend which is distinct. There have not been many studies, except one [10] on the assessment of the effects of plasticizers on fish using VTG induction together with the MT modulation as endpoints. The present study does provide a further insight into the effects of such chemicals on multiple biomarkers used in the aquatic environment.

\section{CONCLUSION}

The key findings of the present study show that an exposure to BPA in adult male koi carp did affect the endpoints investigated. Induction of plasma vitellogenin and suppression of the renal metallothionein levels were observed at the median concentration of $100 \mu \mathrm{g} / \mathrm{L}$ BPA. A multibiomarker approach including molecular biomarkers would be ideal in biomonitoring the aquatic environment for estrogenic chemicals which exhibit different effects at low and high doses. 


\section{ACKNOWLEDGEMENT}

The authors extend their appreciation to the Deanship of Scientific Research at King Saud University for funding the work through research group project no. RGP-VPP-033.

\section{REFERENCES}

1. Vandenberg $L N$, Maffini MV, Sonnenschein C, Rubin BS, Soto AM. Bisphenol-A and the great divide: a review of controversies in the field of endocrine disruption. Endocrinol. Rev. 2009; 30: 75-95.

2. Jobling S, Casey T, Rodgers-Gray J, Oehlmann U, Schulte-Oehlmann S, Pawlowski T, Baunbeck AP, Turner CR, Tyler. Comparative responses of molluscs and fish to environmental estrogens and an estrogenic effluent. Aquat. Toxicol. 2004; 66: 207222.

3. Vethaak $A D$, Lahr J, Schrap $S M$, Belfroid AC, Rijs GBJ, Gerritsen A, de Boer J, Bulder AS, Grinwis GCM, Kuiper RV, Legler J, Murk TAJ, Peijnenburg $W$, Verhaar HJM, de Voogt $P$. An integrated assessment of estrogenic contamination and biological effects in the aquatic environment of The Netherlands. Chemosphere. 2005; 59: 511-524.

4. Witorsch RJ. Endocrine disruptors: can biological effects and environmental risks be predicted? Regul. Toxicol. Pharmacol. 2002; 36: 118-130.

5. Hatef A, Mohammad Hadi Alavi S, Abdulfatah A, Fontaine $P$, Rodina $M$, Linhart $O$. Adverse effects of bisphenol $A$ on reproductive physiology in male goldfish at environmentally relevant concentrations. Ecotoxicol. Environ. Saf. 2012; 76: 56-62.

6. Lindholst C, Pedersen KL, Pedersen SN. Estrogenic response of bisphenol $A$ in rainbow trout (Oncorhynchus mykiss). Aquat. Toxicol. 2000; 48 . 87-94.

7. Mandich A, Bottero S, Benfenati E, Cevasco A, Erratico C, Maggioni S, Massari A, Pedemonte F, Viganò L. In vivo exposure of carp to graded concentrations of bisphenol A. Gen Comp Endocrinol . 2007; 153: 1524.

8. Vasak $M$ and Hasler DW. Metallothioneins: a new functional and structural insights. Curr Opin Chem Biol 2000; 4: 177-183.

9. Costa PM, Repolho T, Caeiro S, Diniz ME, Moura I, Costa MH. Modelling metallothionein induction in the liver of Sparus aurata exposed to metal contaminated sediments. Ecotoxicol. Environ. Saf. 2007; 71:117124.

10. Rhee JS, Raissudin S, Hwang DS, Lee KW, Kim IC, Lee JS. Differential expression of metallothionein (MT) gene by trace metals and endocrine-disrupting chemicals in the hermaphroditic mangrove killifish, Kryptolebias marmoratus. Ecotoxicol. Environ. Saf. 2009; 72: 206-209.

11. Committee for the Purpose of Control and Supervision of Experiments on Animals (CPCSEA) (http://icmr.nic.in/bioethics/final_cpcsea.pdf

12. A.P.H.A. Standard Methods for the Examination of Water and Waste Water. American Public Health Association, Washington, 1991; 1193 pp.

13. Sumpter JP, Jobling S. Vitellogenesis as a biomarker for estrogenic contamination of the aquatic environment. Environ. Health Perspect.1995; 103: 173-178.

14. Kang IJ, Yokota H, Oshima Y, Tsuruda Y, Oe T, Imada $N$, Tadokoro $H$, Honjo $T$. Effects of bisphenol $A$ on the reproduction of Japanese medaka (Oryzias latipes). Environ. Toxicol. Chem. 2002; 21: 23942400.

15. Sohoni $P$, Tyler CR, Hurd K, Caunter J, Hetheridge $M$, Williams T,Woods C, Evans $M$, Toy R, Gargas $M$, Sumpter JP. Reproductive effects of long-term exposure to bisphenol $A$ in the fathead minnow (Pimephales promelas). Environ. Sci. Technol. 2001; 35: 2917-2925.

16. Correia A D, Freitas S, Scholze M, Goncalves JF, Booij $P$, Lamoree $M H$, Mananos $E$, Reis-Henriques MA. Mixtures of estrogenic chemicals enhance vitellogenin response in sea bass. Environ. Health Perspect. 2007; 115 (1): 115-121.

17. Crain $D A$, Eriksen $M$, Iguchi $T$, Jobling $S$, Laufer $H$, LeBlanc GA, Guillette LJ Jr. An ecological assessment of bisphenol-A: Evidence from comparative biology. Reprod Toxicol. 2007; 24: 225239.

18. vom Saal FS and Hughes $C$. An extensive new literature concerning low-dose effects of bisphenol $A$ shows the need for a new risk assessment. Environ Health Perspect. 2005; 113: 926-933.

19. Smirnov LP, Sukhovskaya IV, Nemova NN. Effects of environmental actors on low-molecular-weight peptides of fishes: a review. Russ. J. Ecol. 2005; 36:41-47.

20. Werner J, Wautier K, Evans RE, Baron CL, Kidd K, Palace V. Waterborne ethynyl estradiol induces vitellogenin and alters metallothionein expression in lake trout (Salvelinus namaycush). Aquat. Toxicol. 2003; 62:321-328.

21. Moura Costa JJ, Filipak Neto F, Costa MDM, Morais RN, Esquivel BM, Oliveira Ribeiro CA. Vitellogenesis and other physiological responses induced by 17- $\beta$ estradiol in males of freshwater fish Rhamdia quelen. Comp. Biochem. Physiol.2010; 151:248-257. 